This is an Accepted Manuscript of a book chapter published by Taylor \& Francis in Excellence in construction through innovation on $3^{\text {rd }}$ September 2008: Limbachiya, Mukesh C. \& Kew, Hsein Y. (eds) (2009) Excellence in construction through innovation. London : Taylor \& Francis Group, pp. 119-126. ISBN:

9780415475921.

https://www.routledge.com/Excellence-in-Concrete-Construction-through-Innovation-Proceedings-ofthe/Limbachiya-Kew/p/book/9780415475921 


\title{
Who is the key decision maker in the structural frame selection process?
}

\author{
H. Haroglu, J. Glass \& T. Thorpe. \\ Civil and Building Engineering Department, Loughborough University, UK \\ C. Goodchild \\ The Concrete Centre, UK
}

\begin{abstract}
Selecting the correct structural frame is crucial to a project's feasibility and success, but this decision can have profound implications for the future performance of a building project. In practice, the eventual choice of a frame may involve various parties including client, project manager, cost consultant, structural engineer, architect, main contractor, etc. This paper presents research findings on the levels of influence of these project team members on the structural frame selection process. It describes the results of a two-year study in which various research methods were undertaken including a state-of-the-art literature review, semi-structured interviews and a postal questionnaire survey. The interviews showed that cost consultants, project managers and clients were found to be the most influential people in the structural frame decision-making process, so a postal questionnaire survey was sent to a sample of UK companies operating in these areas to further examine their priorities and views in detail. The data collected was subsequently analyzed and produced a rank ordering of project team members in relation to the influence they have on the choice of frame type at each stage of design process. In fact, they agreed that the structural engineer was the most influential decision-maker in the structural frame selection process. So, this paper asks the question 'who really is the key decision maker?' The conclusions will be of interest to all those concerned with project teams, structural frame design and selection and effective leadership in decision making.
\end{abstract}

Keywords: construction, project teams, structural frames, research

\section{INTRODUCTION}

The framed structure market cuts across several traditionally defined sectors such as residential, education, commercial, health, retail, leisure etc. The UK has a tradition of in-situ concrete construction and in the past in-situ concrete frame construction dominated the frame market. Over the past 20 years concrete has lost significant market share to structural steel in the framed structure market (BRE, 2005). However, concrete's range of structural frame solutions, its thermal efficiency, inherent fire resistance, acoustic and vibration performance, durability and low maintenance ensure that it performs well in a number of UK markets such as commercial and residential buildings (TCC, 2005). Nevertheless, the concrete market has remained steady over the past 18 months, with the exception of reinforcement prices, which are still volatile (Bibby, 2006).

Selecting the correct structural frame is crucial to a project's feasibility and success but this decision on the structural frame type can have profound im- plications for the future performance of a building project (Soetanto et al, 2006a). Furthermore, the project stakeholders' requirements should be captured and taken into consideration so as to ensure apt decisions in the design stage (Soetanto et al, 2006b). Therefore, we tend to make an assumption that the choice of an appropriate structural system during the design stage will lead to a successful project outcome. It is therefore essential to recognize the decision makers in the structural frame selection process. In practice, the eventual choice of a frame may involve various parties including client, project manager, cost consultant, structural engineer, architect, main contractor, etc. So who is the key person to influence what structural frame type is used, and any changes to the design of building project.

This paper describes the results of a two-year study in which various research methods were used including a state-of-the-art literature review, semistructured interviews and a postal questionnaire survey. As a result of these interviews, cost consultants, project managers and clients were found to be the 
most influential people. A postal questionnaire, aimed at these three disciplines, to address the influence of project team members upon choosing appropriate frame type for building projects. The results were analysed using Statistical Package for the Social Sciences (SPSS), and through frequency analysis, confirmed that all project members, perceived by these respondents to the survey, have a great deal of influence in the choice of frame type. The severity index has been further used to rank the project team members (decision makers) for the degree of influence they have in the structural frame selection process. Lastly, Spearman's rho $(\rho)$ analysis has been calculated to establish a measure of agreement between cost consultants, project managers and clients in the rankings of these decision makers at each stage of design process. The study presents findings of a questionnaire survey to establish a ranking of the decision makers (or project team members) at each stage of the design process and to investigate the degree of agreement among cost consultants, project managers, and clients with regards to the rankings. The aim is to provide a view of the different professions, decision makers involved in choosing the structural frame at each key step of the design process.

\section{PROJECT TEAM MEMBERS}

Although the precise contractual obligations of the project participants vary with the procurement option adopted, the project participants must carry out certain essential fundamental functions. The project team consists mainly of client, architect, project manager, structural engineer, cost consultant and main (principal) contractor (CIOB, 2002). Each member of the project team is described below:

Client: A client is a person or organisation paying for the services and can be represented by others, such as clients' representative, employer's agent, project manager, etc. Their chief interest would be to satisfy themselves that the contractor(s) were performing in accordance with the contract and to make sure they are meeting their obligations to pay all monies certified for payments to the consultants and the contractor(s) (CIOB, 2002).

Architect and Structural Engineer: The architect is in charge of the architectural issues, whereas the engineer is concerned with more technical issues. The design should be developed with the involvement of both sides: architect and engineer. There are different driving forces: technical for the engineer whose main aim is to make things "work" without compromising the architects' concept. The architect deals with the appearance of the structure which needs to be true to the concept and fit the context and use (Larsen and Tyas, 2003).

Project manager: Construction and development projects involve the coordinated actions of many different professionals and specialists to achieve defined objectives. The task of project management is to bring the professionals and specialists into the project team at the right time to enable them to make their possible contribution, efficiently. Effective management requires a project manager to add significant and specific value to the process of delivering the project. The value added to the project by project management is unique: no other process or method can add similar value, either qualitatively or quantitatively. The project manager in the main has a role which is principally that of monitoring the performance of the main contractor and the progress of the works (CIOB, 2002).

Cost Consultant (quantity surveyor): The cost consultant has responsibility to advise on building cost and estimating, which can have two distinct roles (Morrison, 1984):

- Part of the design team for cost advice but not management of budget.

- Appointed separately by the client as a cost consultant.

Main contractor: The principal management contractor has a duty to (CIOB, 2002):

- Mobilize all labour, subcontractors, materials, equipment and plant in order to execute the construction works in accordance with the contract documents.

- Ensure the works are carried out in a safe manner

- Indemnifying those working on site and members of the public against the consequences of any injury resulting from the works.

The extent to which the above-mentioned roles are likely to influence the choice of frame type for a building project depends on various matters such as the procurement route adopted, existing attitudes within the organisations involved, type of the building project, project value etc. Nevertheless, a study by Haroglu et al. (2008) identified several issues perceived to be the most important to the structural frame decision-making process and established an agreement between cost consultants, project managers and clients over the significance of these issues influencing the choice of a frame type for a building project. Therefore, it is also important to appreciate the common approach adopted by the members of a typical building project to the structural frame selection process. As a result, this paper examines project team members' influence on the choice of frame type at each stage of the design process. 


\section{DATA COLLECTION}

Although a few research studies have been carried out in this field, a state-of-the-art literature review was first completed in order to understand the process in which the structural frame is normally selected as well as identifying the decision makers in this process. Semi-structured interviews were then conducted with structural engineers to determine the most influential people in the structural frame selection process with the intention of capturing their perceptions in the postal questionnaire survey.

The work stages of the RIBA Plan of Work (2007) are used in this research as the stages are well-known and widely recognized throughout the UK construction industry. We can therefore acknowledge that the design stage consists of three parts: Stage C (Concept), Stage D (Design Development) and Stage E (Technical Design).

\subsection{Semi-structured interviews}

Nine interviews were arranged with structural engineers in selected consultancies to retrieve information about structural frame options and by whom they are evaluated. The core topics discussed during these interviews included: the frame types applied in their projects, influential people in selecting the frame type, and the rationale behind the preferred frame type of their current project. Consequently, cost consultants, project managers and clients were found to be the most influential people in the structural frame decision-making process. These interviews were carried out in total over a two-month period at the interviewees' work places, each lasting approximately 30 minutes. Each interview was tape recorded and subsequently transcribed verbatim and analysed.

\subsection{Questionnaire survey}

As a result of the interviews, cost consultants, project managers and clients were surveyed in an attempt to better understand their views of the relative influence of each project team member on the choice of frame type. The respondents were asked to rate the influence of the project team members on a 4point Likert scale ranging from 0 for 'lowest level' to 3 for 'highest level' as by using an odd number of response points, respondents may be tempted to 'opt-out' of answering by selecting the mid-point (Fellows and Liu, 2003). Having developed the questionnaire, a pilot study was carried out with a sample of nine people from both industry and academia to see how they understand the questions and the response options. Having made a few alterations to the questionnaire as a result of the pilot study, the questionnaire survey was distributed amongst cost consultants, project managers and construction cli- ents to establish the significance and ranking order of the project team members.

The individual respondents were selected randomly from a database of professional companies held by The Concrete Centre (TCC), irrespective of the size of the company. As shown below in Table 1, 239 postal questionnaires were sent to selected names, working for cost managers, project managers and client bodies, in the public and private sectors. As a result, 70 questionnaires were received in total, giving an overall response rate of $29.29 \%$ which is considered sufficient enough to meet the research reliability level compared with the norm of $20-30 \%$ with regard to questionnaire surveys in the construction industry (Akintoye and Fitzgerald, 2000). Of the responses received, 20 were from cost consultants, 25 from project managers and 25 from clients (Table 2).

Table 1. Questionnaire distribution and response rate

\begin{tabular}{llll}
\hline & \multicolumn{2}{l}{$\begin{array}{l}\text { Number of } \\
\text { Questionnaires }\end{array}$} & \\
\cline { 2 - 3 } $\begin{array}{l}\text { Respondent } \\
\text { group }\end{array}$ & Distributed & Returned & $\begin{array}{l}\text { Response } \\
\text { rate \% }\end{array}$ \\
\hline Cost Consultant & 86 & 20 & 23.26 \\
Project Manager & 74 & 25 & 33.78 \\
Client & 79 & 25 & 31.65 \\
\hline Total & 239 & 70 & 29.29 \\
\hline
\end{tabular}

The respondents were also asked about their influence over the choice of frame type for a building project in order to appreciate the value of each individual's response to this survey. Below Figure 1 shows that $44 \%$ of the respondents had a great deal of influence over the choice of frame type for a building project whereas only $9 \%$ had none, which suggests that the respondents were generally influential in the structural frame selection, and possessed an immense understanding in the structural frame selection process.

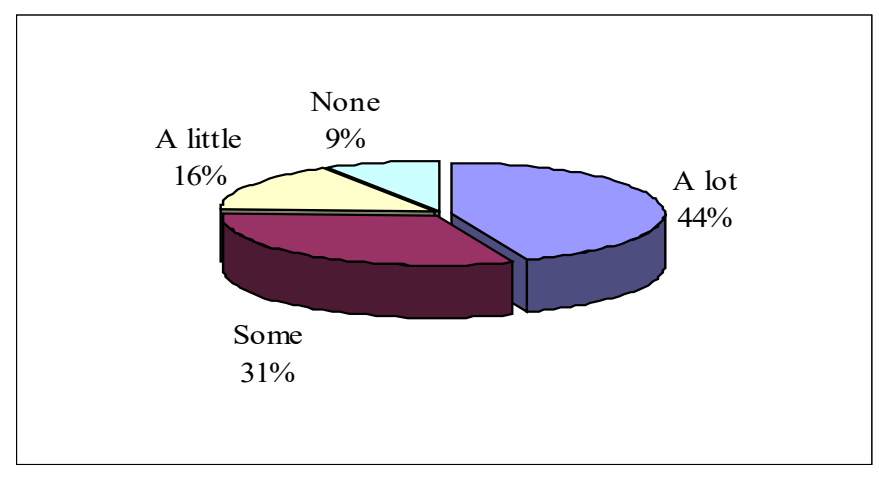

Figure 1. The influence of the respondents on the choice of frame type 
The results confirmed that all of the project team members included in the survey were considered to be influential, proving the validity of the decision makers of a typical building project as a basis for consideration in the choice of frame type. Because of this, and the considerable degree of influence the respondents have on the choice of frame type, the returned sample was considered to be representative of the actual decision-making population. The next section illustrates some of the results in detail.

\section{ANALYSIS AND RESULTS}

The questionnaire was designed to provide predominantly descriptive data. An ordinal scale was used to rank the responses in this survey that there was no indication of distance between scaled points or commonality of scale perceptions in the Likert scale by respondents. It essentially provided a hierarchical ordering. Therefore, non-parametric tests were used in the analysis because non-parametric statistical tests are available to treat data which is inherently in ranks (Siegel and Castellan, 1956; Johnson and Bhattacharyya, 1996); the analysis was then carried out on the ranks rather than the actual data. The nonparametric procedures adopted for this study were frequency, severity index analysis, and Spearman's rho $(\rho)$ test.

First of all, frequency analysis was applied to examine the degree of influence for each project team member. The severity index was used to rank the project team members for the degree of influence. The results of the frequency analysis and the ranking (severity index) have been based on analyses of all the completed responses. Individuals within these three disciplines were asked to provide information based on their own experiences from one of their projects that had recently started on site. However, these experiences were gained from distinct disciplines at each part of design stage, so it was essential to conduct a comparative analysis to distinguish between their responses. Since the variables are at the ordinal level, there are two prominent methods for examining the relationship between pairs of ordinal variables namely, Spearman's rho ( $\rho)$ (or Spearman rank correlation rs) and Kendall's tau $(\tau)$ - the former being more common in reports of research findings (Brymer and Cramer, 2005). Kendall's tau usually produces slightly smaller correlations, but since Spearman's rho is more commonly used by researchers, it was decided to be applied in this case. The Spearman's rho correlation coefficient is produced by using the rank of scores rather than the actual raw data (Brymer and Cramer, 2005; Hinton et al., 2004; Kinnear and Gray, 2006). The Statistical Package for the Social Sciences (S.P.S.S.) was used to compute and run these statistical analyses.

\subsection{Ranking the project team members: frequency and severity index analysis}

This stage of the statistical analysis ranked the project team members in order of influence for each part of design process. In this case, frequency analysis was first carried out to obtain the frequency of the respondents, using the Statistical Package for the Social Sciences (S.P.S.S.). The frequencies of responses were therefore used to calculate severity indices for each project team member via Equation 1 (Ballal, 2000):

S.I. $=\left[\sum_{i=1}^{i=n} \omega i * f i\right] * 100 \% / \mathrm{n}$

Where: S.I. $=$ severity index; $f i=$ frequency of responses; $\omega i=$ weight for each rating; $\mathrm{n}=$ total number of responses

Since the 4-point Likert scale ranging from 0 for 'lowest level' to 3 for 'highest level', was used for the survey in order for the respondents not to be tempted to 'opt-out' of answering by selecting the mid-point, the weight assigned to each rating and is calculated by the following Equation 2 (Ballal, 2000):

$\omega i=($ Rating in scale $) /($ number of points in a scale $)$

Therefore, $\omega 0=0 / 4=0 ; \omega 1=1 / 4=0.25$; $\omega 2=$ No mid-point in the scale; $\omega 3=3 / 4=0.75$; $\omega 4=4 / 4=1$

Example: An example of the calculation for the severity index is given below:

Influence of "Architect" at the Stage D:

\begin{tabular}{llllll}
\hline & $\begin{array}{l}\text { Not } \\
\text { imp=0 }\end{array}$ & $\begin{array}{l}\text { Of lit- } \\
\text { tle } \\
\text { imp=1 }\end{array}$ & $\begin{array}{l}\text { Quite } \\
\text { imp=2 }\end{array}$ & $\begin{array}{l}\text { Extremely } \\
\text { imp=3 }\end{array}$ & $\begin{array}{l}\text { Total } \\
\text { (n) }\end{array}$ \\
\cline { 2 - 6 } $\begin{array}{l}\text { Frequencies } \\
\text { (fi) }\end{array}$ & 0 & 11 & 30 & 24 & 65 \\
\hline
\end{tabular}

S.I. $=((0 * 0+11 * 0.25+30 * 0.75+24 * 1) / 65) * 100=75.77 \%$

The project team members were then ranked in order of value of severity index, the highest value having a rank of 1 , and the lowest value assigned a rank of 6 . Tables 2, 3 and 4 present the project team members ranked in terms of influence for each stage of the design process. In addition to that, Figure 2 
displays the respondents' view of the degree of influence of the project team members on the choice of frame type during the design process.

Table 2. Issues ranked in Concept Design

\begin{tabular}{|c|c|c|c|c|c|c|c|}
\hline \multicolumn{8}{|c|}{ Concept (Stage C of RIBA) } \\
\hline \multirow[t]{2}{*}{$\begin{array}{l}\text { Project } \\
\text { Team } \\
\text { Members }\end{array}$} & \multicolumn{4}{|c|}{$\begin{array}{l}\text { Frequency of re- } \\
\text { sponses for score } \\
\text { of }\end{array}$} & \multirow[t]{2}{*}{$\begin{array}{l}\text { No. of } \\
\text { responses }\end{array}$} & \multirow{2}{*}{$\begin{array}{l}\text { Severity } \\
\text { Index } \\
\%\end{array}$} & \multirow[t]{2}{*}{$\begin{array}{l}\text { SPSS } \\
\text { Rank }\end{array}$} \\
\hline & 0 & 1 & 2 & 3 & & & \\
\hline $\begin{array}{l}\text { Structural } \\
\text { Engineer }\end{array}$ & 1 & 6 & 17 & 42 & 66 & 85.23 & 1 \\
\hline Architect & 0 & 9 & 28 & 29 & 66 & 79.17 & 2 \\
\hline $\begin{array}{l}\text { Cost Con- } \\
\text { sultant }\end{array}$ & 2 & 13 & 25 & 27 & 67 & 73.13 & 3 \\
\hline $\begin{array}{l}\text { Project } \\
\text { Manager }\end{array}$ & 1 & 19 & 31 & 12 & 63 & 63.49 & 4 \\
\hline Client & 4 & 22 & 20 & 18 & 64 & 60.16 & 5 \\
\hline $\begin{array}{l}\text { Main } \\
\text { Contractor }\end{array}$ & 21 & 14 & 19 & 11 & 65 & 44.23 & 6 \\
\hline
\end{tabular}

Table 3. Issues ranked in Design Development

\begin{tabular}{|c|c|c|c|c|c|c|c|}
\hline \multicolumn{8}{|c|}{ Design Development (Stage D of RIBA) } \\
\hline \multirow{2}{*}{$\begin{array}{l}\text { Project } \\
\text { Team } \\
\text { Members }\end{array}$} & \multicolumn{4}{|c|}{$\begin{array}{l}\text { Frequency of re- } \\
\text { sponses for score } \\
\text { of }\end{array}$} & \multirow[t]{2}{*}{$\begin{array}{l}\text { No. of } \\
\text { responses }\end{array}$} & \multirow{2}{*}{$\begin{array}{l}\text { Severity } \\
\text { Index } \\
\%\end{array}$} & \multirow[t]{2}{*}{$\begin{array}{l}\text { SPSS } \\
\text { Rank }\end{array}$} \\
\hline & 0 & 1 & 2 & 3 & & & \\
\hline $\begin{array}{l}\text { Structural } \\
\text { Engineer }\end{array}$ & 0 & 6 & 15 & 45 & 66 & 87.50 & 1 \\
\hline $\begin{array}{l}\text { Cost Con- } \\
\text { sultant }\end{array}$ & 1 & 8 & 29 & 29 & 67 & 78.73 & 2 \\
\hline Architect & 0 & 11 & 30 & 24 & 65 & 75.77 & 3 \\
\hline $\begin{array}{l}\text { Project } \\
\text { Manager }\end{array}$ & 2 & 17 & 26 & 18 & 63 & 66.27 & 4 \\
\hline $\begin{array}{l}\text { Main } \\
\text { Contractor }\end{array}$ & 10 & 9 & 27 & 19 & 65 & 63.85 & 5 \\
\hline Client & 5 & 18 & 27 & 14 & 64 & 60.55 & 6 \\
\hline
\end{tabular}

Table 4. Issues ranked in Technical Design

\begin{tabular}{|c|c|c|c|c|c|c|c|}
\hline \multicolumn{8}{|c|}{ Technical Design (Stage E of RIBA) } \\
\hline \multirow{2}{*}{$\begin{array}{l}\text { Project } \\
\text { Team } \\
\text { Members }\end{array}$} & \multicolumn{4}{|c|}{$\begin{array}{l}\text { Frequency of re- } \\
\text { sponses for } \\
\text { score of }\end{array}$} & \multirow[t]{2}{*}{$\begin{array}{l}\text { No. of } \\
\text { responses }\end{array}$} & \multirow{2}{*}{$\begin{array}{l}\text { Severity } \\
\text { Index } \\
\%\end{array}$} & \multirow[t]{2}{*}{$\begin{array}{l}\text { SPSS } \\
\text { Rank }\end{array}$} \\
\hline & 0 & 1 & 2 & 3 & & & \\
\hline $\begin{array}{l}\text { Structural } \\
\text { Engineer }\end{array}$ & 0 & 3 & 22 & 40 & 65 & 88.08 & 1 \\
\hline $\begin{array}{l}\text { Main } \\
\text { Contractor }\end{array}$ & 4 & 10 & 14 & 38 & 66 & 77.27 & 2 \\
\hline Architect & 5 & 14 & 26 & 19 & 64 & 65.63 & 3 \\
\hline $\begin{array}{l}\text { Cost Con- } \\
\text { sultant }\end{array}$ & 4 & 17 & 26 & 19 & 66 & 64.77 & 4 \\
\hline $\begin{array}{l}\text { Project } \\
\text { Manager }\end{array}$ & 3 & 18 & 27 & 14 & 62 & 62.50 & 5 \\
\hline Client & 6 & 24 & 19 & 14 & 63 & 54.37 & 6 \\
\hline
\end{tabular}

Figure 2 shows the opinions of the respondents of the level of influence that the project team members have on the choice of frame type at the three stages of design process. 'Structural Engineer' appeared to be the most influential at all stages. Note the increasing influence of the 'Structural Engineer' and especially the 'Main Contractor', with the influence of the other members decreasing.

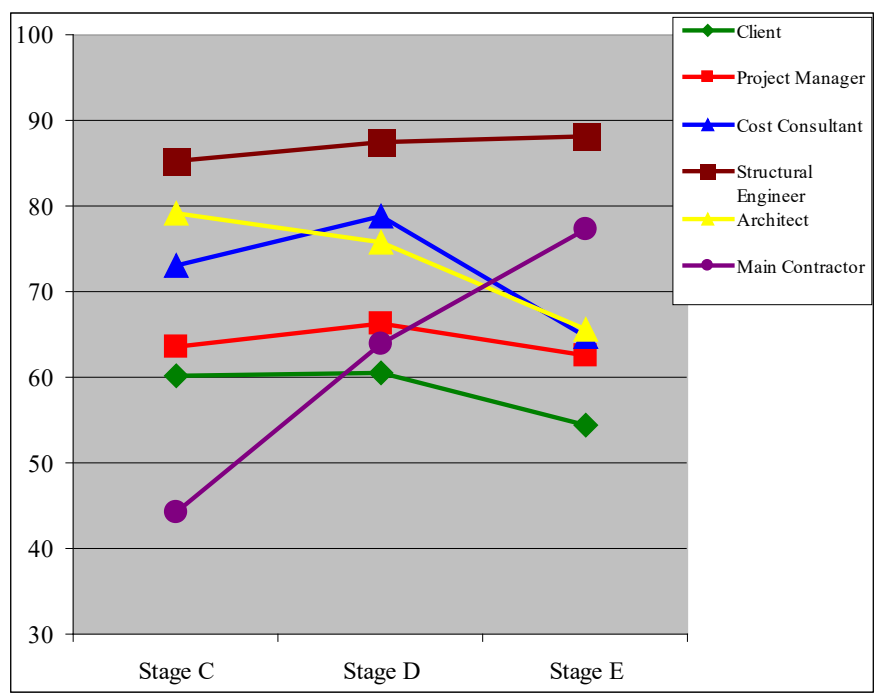

Figure 2. Respondents' view of the influence of the project team members at all design stages

\subsection{Investigating agreement: Spearman's rho $(\rho)$ test}

To examine the agreement, if there is any, between three disciplines on the ranking of the project team members in relation to the influence they have in the structural frame selection process, Spearman's rho ( $\rho)$ test was employed. The frequency of responses and severity indices were again computed for each group to generate a separate ranking of the project team members, as shown in Tables 5, 6 and 7. Additionally, the Figures 3, 4 and 5 were used to display the results of the analyses for the readers of this paper to assimilate more readily.

Table 5. Comparison of severity index and ranking for each group at Concept Design

\begin{tabular}{lcccccc} 
& \multicolumn{5}{c}{ Concept (Stage C of RIBA) } \\
\cline { 2 - 7 } $\begin{array}{l}\text { Project } \\
\text { Team } \\
\text { Members }\end{array}$ & $\begin{array}{l}\text { Cost Con- } \\
\text { sultant }\end{array}$ & $\begin{array}{l}\text { Project Man- } \\
\text { ager }\end{array}$ & Client \\
\cline { 2 - 7 } & S.I \% & $\begin{array}{l}\text { SPSS } \\
\text { Rank }\end{array}$ & S.I \% & $\begin{array}{l}\text { SPSS } \\
\text { Rank }\end{array}$ & S.I \% & $\begin{array}{c}\text { SPSS } \\
\text { Rank }\end{array}$ \\
\hline $\begin{array}{l}\text { Cost Con- } \\
\text { sultant } \\
\begin{array}{l}\text { Structural } \\
\text { Engineer }\end{array}\end{array}$ & 84.21 & 1 & 65.22 & 3 & 72.00 & 3 \\
\hline
\end{tabular}




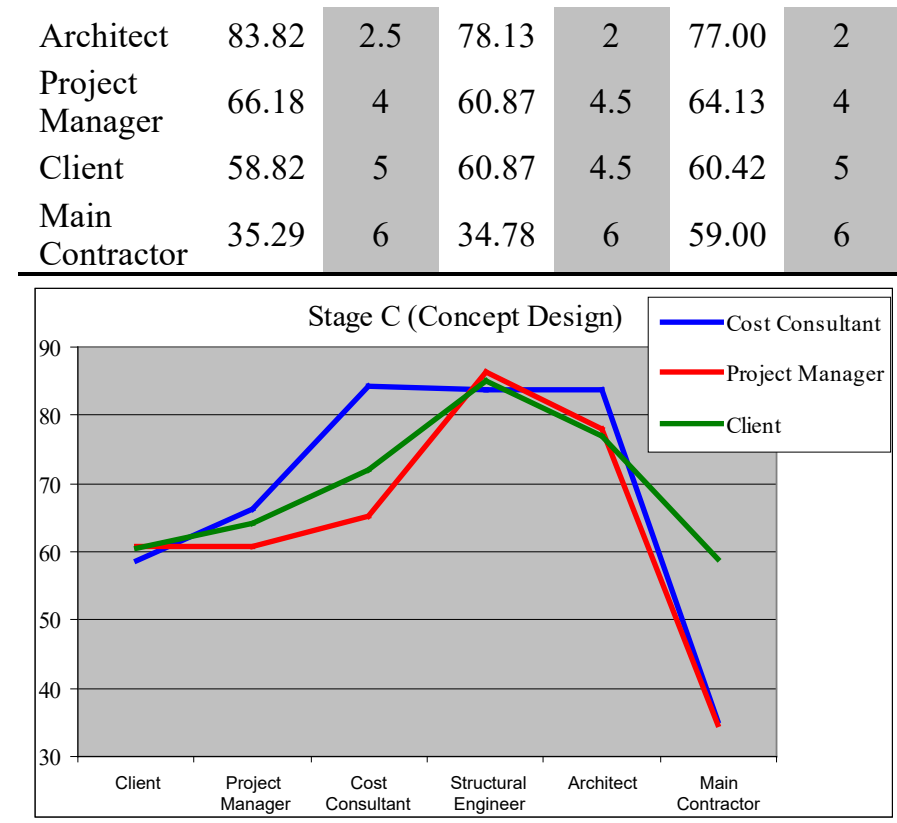

Figure 3 . The views of the three sets of respondents on the degree of influence the project team members have at stage $\mathrm{C}$

Table 6. Comparison of severity index and ranking for each group at Design Development

\section{Design Development (Stage D of RIBA)}

\begin{tabular}{lllllll}
\multirow{2}{*}{$\begin{array}{l}\text { Project } \\
\text { Team } \\
\text { Members }\end{array}$} & \multicolumn{2}{l}{$\begin{array}{l}\text { Cost Con- } \\
\text { sultant }\end{array}$} & \multicolumn{2}{l}{$\begin{array}{l}\text { Project Man- } \\
\text { ager }\end{array}$} & Client & \\
\cline { 2 - 6 } & S.I \% & $\begin{array}{l}\text { SPSS } \\
\text { Rank }\end{array}$ & S.I \% & $\begin{array}{l}\text { SPSS } \\
\text { Rank }\end{array}$ & S.I \% & $\begin{array}{l}\text { SPSS } \\
\text { Rank }\end{array}$
\end{tabular}

\begin{tabular}{lllllll}
\hline $\begin{array}{l}\text { Structural } \\
\text { Engineer }\end{array}$ & 83.82 & 1 & 87.50 & 1 & 90.00 & 1 \\
$\begin{array}{l}\text { Cost Con- } \\
\text { sultant }\end{array}$ & 81.58 & 2 & 73.91 & 2 & 81.00 & 2 \\
$\begin{array}{l}\text { Architect } \\
\text { Project }\end{array}$ & 80.88 & 3 & 72.83 & 3 & 75.00 & 4 \\
$\begin{array}{l}\text { Manager } \\
\text { Main }\end{array}$ & 61.76 & 4 & 66.30 & 4 & 69.57 & 5 \\
Contractor & 60.29 & 5 & 51.09 & 6 & 78.00 & 3 \\
Client & 55.88 & 6 & 59.78 & 5 & 64.58 & 6 \\
\hline
\end{tabular}

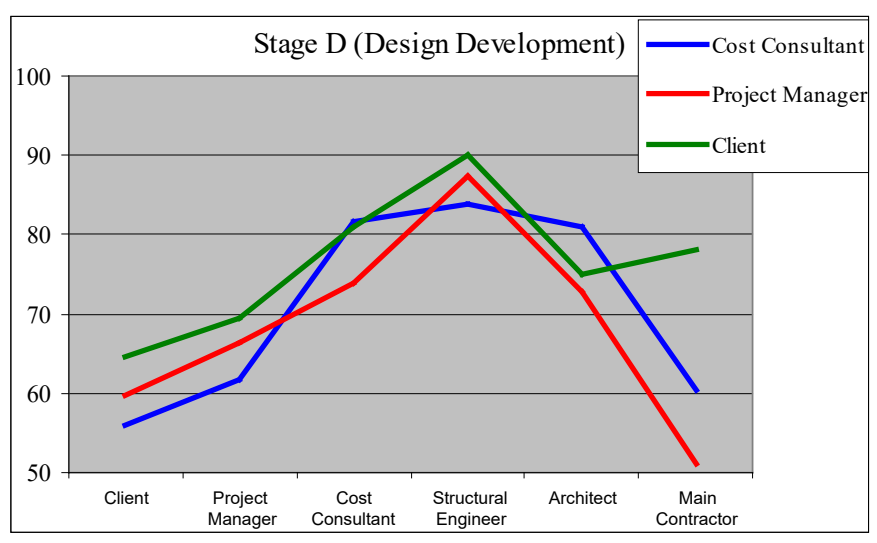

Figure 4. The views of the three sets of respondents on the degree of influence the project team members have at stage D

Table 7. Comparison of severity index and ranking for each group at Technical Design

Technical Design (Stage E of RIBA)

\begin{tabular}{lcccccc} 
& \multicolumn{7}{c}{$\begin{array}{l}\text { Project } \\
\text { Team } \\
\text { Members }\end{array}$} & $\begin{array}{l}\text { Cost Con- } \\
\text { sultant }\end{array}$ & \multicolumn{4}{l}{$\begin{array}{l}\text { Project Man- } \\
\text { ager }\end{array}$} & Client & \\
\cline { 2 - 7 } & S.I \% & $\begin{array}{l}\text { SPSS } \\
\text { Rank }\end{array}$ & S.I \% & $\begin{array}{l}\text { SPSS } \\
\text { Rank }\end{array}$ & S.I \% & $\begin{array}{c}\text { SPSS } \\
\text { Rank }\end{array}$ \\
\hline $\begin{array}{l}\text { Structural } \\
\text { Engineer }\end{array}$ & 86.76 & 1 & 91.30 & 1 & 86.00 & 2 \\
$\begin{array}{l}\text { Cost Con- } \\
\text { sultant }\end{array}$ & 73.68 & 2 & 57.95 & 5 & 64.00 & 4 \\
$\begin{array}{l}\text { Main } \\
\text { Contractor }\end{array}$ & 72.06 & 3 & 70.83 & 2 & 87.00 & 1 \\
$\begin{array}{l}\text { Project } \\
\text { Manager }\end{array}$ & 64.71 & 4 & 62.50 & 4 & 60.87 & 5 \\
$\begin{array}{l}\text { Architect } \\
\text { Client }\end{array}$ & 61.76 & 5 & 63.64 & 3 & 70.00 & 3 \\
\hline
\end{tabular}

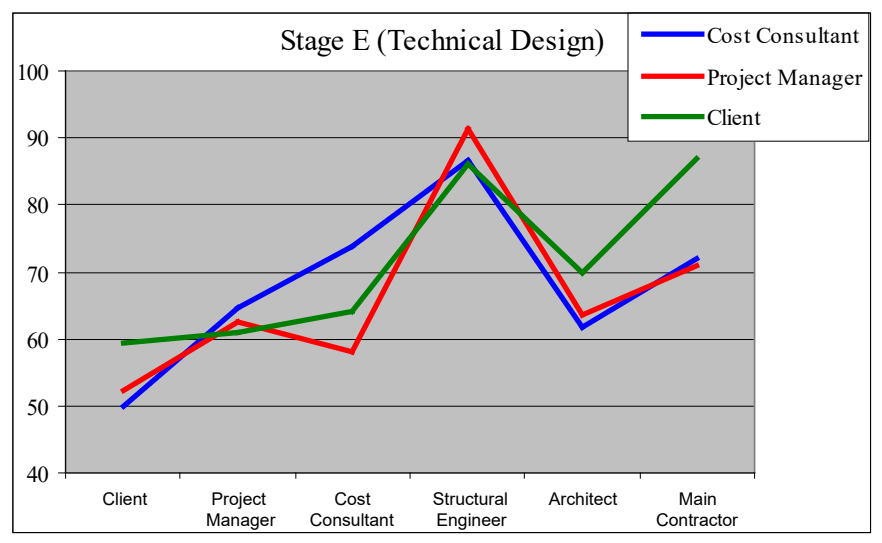

Figure 5. The views of the three sets of respondents on the degree of influence the project team members have at stage $\mathrm{E}$

As a result of this, Spearman's rho ( $\rho$ ) (or Spearman rank correlation rs) test was computed using the Statistical Package for the Social Sciences (S.P.S.S.). The three groups are compared statistically by applying Spearman Rho test. Table 8 presents 
all of the Spearman Rho correlations computed, using SPSS, as shown below.

Table 8. Spearman's Rho (r) test results between the rankings of three groups

\begin{tabular}{llll}
\hline & \multicolumn{3}{c}{ Correlations } \\
\cline { 2 - 4 } $\begin{array}{l}\text { Design Stag- } \\
\text { es of RIBA }\end{array}$ & $\begin{array}{l}\text { Cost Con- } \\
\text { sultant vs. } \\
\text { Project } \\
\text { Manager }\end{array}$ & $\begin{array}{l}\text { Cost Con- } \\
\text { sultant vs. } \\
\text { Client }\end{array}$ & $\begin{array}{l}\text { Project } \\
\text { Manager } \\
\text { vs. Client }\end{array}$ \\
\hline Stage C & 0.794 & $0.812^{*}$ & $0.986^{* *}$ \\
Stage D & $0.943^{* *}$ & $0.829^{*}$ & 0.657 \\
Stage E & 0.600 & 0.600 & $0.886^{*}$ \\
\hline
\end{tabular}

Note: ${ }^{* *},{ }^{*}$ denotes 'strong' with $\mathrm{p}<0.01$ and 'some' with $\mathrm{p}<$ 0.05 statistical evidence of significant similarities

The level of significance was set by SPSS both at 0.05 and 0.01 levels, which indicated the degree of relationship amongst the three rankings. $p<0.05$ means that there is less than a 5 per cent chance that there is no relationship between the two rankings, whereas $p<0.01$ means that there is less than a 1 percent chance, and can be accepted at the 99\% confidence level (Bryman and Cramer, 2005; Fellows and Liu, 2003; Field, 2000). From Table 8, most of the correlations written with asterisks did achieve statistical significance at either $p<0.05$ or $p<0.01$ which confirmed that there are strong relationships amongst the rankings of three groups, assuring that agreements amongst the three rankings was much higher than it would occur by chance. As a result, it may be concluded that the rankings obtained from the three groups, as given by the severity index analysis, was consensual amongst the respondents.

\section{FINDINGS AND DISCUSSION}

With regard to the results of frequency and severity index analyses, all of the project team members were ranked by the respondents to the survey in order of influence they have at each stage of the design process. The Spearman's rho test was then applied to establish the consensus between the three sets of respondents in relation to the rankings of the project team members at each stage.

As the design develops, note the increasing influence of the structural engineer and especially the contractor, with the influence of the other members decreasing, as shown in Figure 2. It is evident that 'Structural Engineers' influence was perceived to be far more than the other project team members at all times during the design process. However, the structural engineers interviewed indicated that they were not the most influential party in the choice of frame type, citing cost consultants, project managers and clients as more influential. This may be because structural engineers are not aware of their influence, or because they do not want to pronounce that they are powerful in the structural frame selection process. On the other hand, 'Clients' were perceived to be unexpectedly the least influential decision-maker for the duration of design process in general. 'Architect' and 'Cost Consultant' were perceived to be very influential during stages $\mathrm{C}$ and $\mathrm{D}$ when the structural frame of a building project is generally selected (Ballal and Sher, 2003). In addition, regarding the magnitude of the severity indices, there appears to be a relatively large gap separating the 'Structural Engineer', 'Architect' and 'Cost Consultant' as the top three decision makers from the rest at the stages $\mathrm{C}$ and $\mathrm{D}$, as shown in Tables 2 and 3. 'Project Manager's influence is highest at stage D where it was ranked the fourth by the respondents which indicates that 'Project Manager' is not considered with the same degree of influence as are 'Structural Engineer', 'Architect' and 'Cost Consultant'. In addition, 'Main Contractors' influence rises to be number two at stage E. However, it may well be too late for the main contractor to influence the choice of frame type at this stage.

From the results of the Spearman's rho $(\rho)$ test, there appeared to be a significant agreement in the rankings of project team members amongst the three groups and the degree of agreement was higher than would have occurred by chance, as shown in Table 8. The degree of agreement amongst the three groups is higher at stages $\mathrm{C}$ and $\mathrm{D}$ than it is at stage $\mathrm{E}$ as regards the correlations written with asterisks in Table 8. 'Structural Engineer' is generally agreed upon to be the most influential decision-maker in the selection of a frame type. Although the cost consultants, project managers and client were in good agreement with each other in relation to the degree of influence of the decision makers (or project team members), they differ in some places, particularly the degree of influence of 'Main Contractor' at stages D and E. 'Main Contractor' was considered to be very influential by clients in the structural frame selection process at stages $\mathrm{D}$ and $\mathrm{E}$, whereas cost consultants and project managers did not consider 'Main Contractor' very influential at stage D (it was ranked the least influential decision-maker by project managers). A possible reason for this is that contractor involvement in a building project at stage D is perceived to be higher or more effective by clients than it is in reality. In addition, not surprisingly whilst 'Cost Consultant' was considered to be the second most influential at stage $\mathrm{E}$ by cost consultants, it was ranked by project managers and clients to be the fifth and fourth respectively.

As in any research based on a questionnaire survey, this study is subject to some biases and limitations. Firstly, with regard to the use of The Concrete Centre's database; although it may not necessarily represent the whole UK construction industry, it is large (25,000 names), up to date and nationwide. Secondly, since the postal questionnaire was sent 
through the post from The Concrete Centre to the respondent, it may have been presumed that the main thrust of this survey was about concrete frames rather than structural frames in general.

None-the-less, it can be said that the ranking of the six decision makers obtained from the respondents to the survey are representative of the views of the UK construction industry in relation to the structural frame selection process. Since selecting the correct structural frame is crucial to a project's feasibility and success, the assumption made earlier on in this paper was that the choice of an appropriate structural system will lead to a successful project outcome. The rank ordering at each stage of design process can therefore be of much interest to all those concerned with project teams, structural frame design and selection and effective leadership in decision making. Above all, the findings can give useful insights into the frame industry. For instance, it is evident that 'Main Contractor' appeared to have a significant input at both stages $\mathrm{D}$ and $\mathrm{E}$ which means that contractors should be a major audience in the frame market.

\section{CONCLUSION}

The decision on the choice of frame has significant short- and long-term implications for the building's function and its client's needs (Soetanto et al., 2007). Having undertaken a literature review and semi-structured interviews, cost consultants, project managers and clients were found to be the most influential decision makers in the selection of structural frame process. So this study asked these people the question "who really was the key decision maker?' through a postal questionnaire survey. The respondents to the survey were requested to base their answers on one of their projects that had recently started on site. So, as project participants moved through the design stages, their influence was evaluated by the respondents. A total of 70 detailed responses were received and analyzed, providing a number of useful insights into the view of professionals about the decision makers in the structural frame selection process.

As a result of the questionnaire survey, the structural engineer was evidently found to be the most influential decision-maker in the choice of frame at each stage of design process. This is an outstanding contrast to the results of semi-structured interviews carried out with the structural engineers earlier on in this research. Further research in this field might examine how the key decision makers in the choice of frame for a building project vary by sector, project value, type of procurement route, etc. Furthermore, it was found that the contractor's influence is particularly high, as perceived by the respondents, at stages $\mathrm{D}$ and $\mathrm{E}$ which indicates that contractors could make quite an impact on the choice of frame type for a building project.

In conclusion there were some areas of disagreement amongst the three sets of respondents, such as the main contractor. This warrants specific research in this field. It is not known yet whether the main contractor could exert influence to change the frame type or any specifications of a building project after being involved. Hence there confirms to be a gap in knowledge about who the key decision maker is and while this paper has offered some key insights, the role of the contractor now appears to be next area of focus for research, particularly if we are seeking a clear model for how this area of decision making works in practice.

\section{ACKNOWLEDGEMENT}

The research project reported in this article was funded by the Engineering and Physical Sciences Research Council (EPSRC) along with The Concrete Centre (TCC) and this support is gratefully acknowledged. The authors are grateful to all of those involved with the project. The authors would also like to give their special thanks to all the people that had spent their valuable time to complete and return the questionnaire.

\section{REFERENCES}

Akintoye, A., and Fitzgerald, E. 2000. A survey of current cost estimating practices in the UK, Construction Management and Economics, No: 2, 18: 161-172.

Ballal, T. M. 2000. The Use of Artificial Neural Networks for Modelling Buildability in Preliminary Structural Design. Ph.D. thesis, Loughborough University of Technology, UK.

Ballal, T.M.A., and Sher, W.D. 2003. Artificial Neural Network for the Selection of Buildable Structural System. Engineering, Construction and Architectural Management, 10 (4): 263-271.

Bibby, G. 2006. Structures update, Building Magazine, 3: 6469.

Bryman, A., and Cramer, D. 2005. Quantitative Data Analysis with SPSS 12 and 13: A Guide for Social Scientists. London: Taylor \& Francis Group.

Building Research Establishment (BRE) Report 2005. Towards a successful future for concrete frame construction in the $U K$, prepared for DTI, December 2005. London: Building Research Establishment Ltd.

Fellows, R. and Liu, A. 2003. Research Methods for Construction. Oxford: Blackwell Science Ltd.

Field, A. 2000. Discovering Statistics Using SPSS for Windows: Advanced Techniques for Beginners. California: SAGE Publications Inc.

Haroglu, H., Glass, J., Thorpe, T. and Goodchild, C. 2008. Critical Factors Influencing the Choice of Frame Type at Early Design. CSCE 2008 Annual Conference June 10-13, 2008, Canada.

Hinton, P.R, Brownlow, C., McMurray, I., and Cozens, B. 2004. SPPS Explained. London: Routledge.

Johnson, R. A. and Bhattacharyya, G. K. 1996. Statistics: Principles and Methods. New York: Wiley. 
Kinnear, P.R. and Gray, C.D. 2006. SPSS 14 MADE SIMPLE. New York: Psychology Press.

Larsen, O.P., and Tyas, A. 2003. Conceptual Structural Design: bridging the gap between architects and engineers. London: Thomas Telford.

Morrison, N. 1984. The accuracy of quantity surveyors' cost estimating, Construction Management and Economics, No: 1, 2: 57-75.

RIBA 2007. The RIBA Plan of Work Stages 2007. See http://www.snapsurveys.com/learnandearn/ribaoutlineplano fwork2007.pdf

Siegel S. \& N.J. Castellan, 1956. Nonparametric statistics for the behavioral sciences. McGraw-Hill, US.

Soetanto, R., Dainty, A. R. J., Glass, J. and Price, A. D. F. 2006a. A Framework for Objective Structural Frame Selection, Structures \& Buildings, 159: 45-52.

Soetanto, R., Dainty, A.R.J., Glass, J. and Price, A.D.F. 2006 b. Towards an explicit design de-cision process: the case of structural frame, Con-struction Management and Economics, 24: 603-614.

Soetanto, R., Glass, J., Dainty, A.R.J., and Price, A.D.F. 2007. Structural Frame Selection: Case Studies of Hybrid Concrete Frames, Building Research \& Information, 35(2): 206-219.

The Chartered Institute of Building (CIOB). 2002. Code of Practice for Project Management for Construction and Development. Oxford: Blackwell Publishing.

The Concrete Centre (TCC) 2006. Benefits of Concrete. Surrey: The Concrete Centre. Available See http://www.concretecentre.com/main.asp?page $=13$ 